\title{
Respon Kunir Putih (Kaempferia rotunda) terhadap Pemberian IBA dan BAP pada Kultur In Vitro
}

\section{Response of Kaempferia Rotunda with Addition IBA and BAP on In Vitro Culture}

\author{
Ahmad Yunus ${ }^{1)}$, Muji Rahayu ${ }^{1)}$, Samanhudi ${ }^{1)}$, Bambang Pujiasmanto ${ }^{1)}$, Himawan Joko Riswanda ${ }^{2)}$
}

\begin{abstract}
Kaempferia rotunda that long ago been used to treat gastrointestinal disorders and also treat cancer, has promising opportunities to cultivate. There are several obstacles in cultivation today. Plant propagation by in vitro can be one solution. Basic media and plant growth promoting substance usage is an important factor which has to be concerned. Research aiming to produce high quality seed and in large numbers. Research has been carried out in Tissue Culture Laboratory, Agriculture Faculty, Sebelas Maret University, Surakarta, during July 2014 to August 2015. This research was used MS (Murashige and Skoog) media with combination treatment of each IBA and BAP concentration of $0,1,2,3$, and $4 \mathrm{ppm}$. The number of shoots that appear on the explant is the main observation variables. The results showed IBA and BAP are likely to affect the appearance of buds as much as 2 pieces in each explant at $0 \mathrm{ppm}$ IBA treatment.
\end{abstract}

Key words : Kaempferia rotunda, kunir putih, IBA, BAP

\section{PENDAHULUAN}

Indonesia sejak dahulu terkenal sebagai salah satu negara yang memiliki bermacam jenis tanaman rempah dan tanaman obat. Terdapat banyak tanaman yang telah dimanfaatkan sebagai obat tradisional. Salah satu jenis tanaman obat adalah kunir putih (Kaempferia rotunda). Kunir putih ( $K$. rotunda) yang sejak dahulu telah digunakan untuk mengobati gangguan pencernaan dan juga mengobati kanker, bila dikembangkan memiliki peluang yang cukup menjanjikan. Senyawa bioaktif berupa pinostrobin dapat memperbaiki histopatologi jaringan yang terserang kanker (Atun dan Arianingrum 2015).

Terdapat beberapa kendala dalam pembudidayaan kunir putih sampai saat ini. Perbanyakan tanaman secara in vitro dapat menjadi salah satu solusinya. Menurut Hendaryono dan Ari (1994), Kultur in vitro dapat menghasilkan tanaman dalam jumlah yang besar dengan waktu yang singkat dan memiliki sifat serta kualitas yang sama. Media dasar dan zat pengatur tumbuh yang tepat merupakan faktor yang harus diperhatikan.

Fungsi dari ZPT yaitu untuk merangsang pertumbuhan dalam kultur sel, jaringan dan organ. Menurut Nisak et al. (2012), jenis sitokinin yang sering digunakan dalam kultur jaringan adalah BAP (Benzyl Amino Purin) karena lebih tahan terhadap degradasi dan mempunyai aktivitas tinggi dalam memacu pembelahan sel. Auksin yang digunakan yaitu IBA (Indole Butyric Acid) yang mempunyai sifat lebih stabil daripada IAA dan NAA, karena IBA tidak rusak oleh pengaruh oksidasi dan tingkat toksisitas yang rendah. Penelitian Arni putri et al. pada tahun 2003

${ }^{1)}$ Lecturer Staff of Study of Agrotechnology, Faculty of Agriculture University of Sebelas Maret (UNS) in Surakarta.

2) Undergraduation Student of Study Program of Agrotechnology, Faculty of Agriculture University of Sebelas Maret (UNS) in Surakarta.

Contact Author: yunus@staff.uns.ac.id menunjukkan bahwa pemberian IAA sampai 1,5 ppm akan meningkatkan jumlah akar kunir putih tetapi cenderung memiliki perakaran yang pendek. Berdasarkan uraian diatas perlu dilakukan penelitian untuk mengetahui konsentrasi IBA dan BAP yang tepat agar dapat meningkatkan pertumbuhan eksplan kunir putih dan memperbanyak tumbuhnya tunas sehingga dapat dihasilkan bibit dalam jumlah banyak.

\section{METODE PENELITIAN}

Penelitian dilakukan di Laboratorium Fisiologi Tumbuhan dan Bioteknologi, Fakultas Pertanian, Universitas Sebelas Maret, Surakarta, yang dimulai dari Juli 2014 sampai Agustus 2015. Bahan yang digunakan dalam penelitian ini adalah umbi atau rimpang Kaempferia rotunda dari lapang yang ditumbuhkan tunasnya. Tunas ini yang akan digunakan sebagai eksplan, setelah melalui tahap sterilisasi. Peubah yang diamati adalah: Saat muncul tunas, jumlah tunas, tinggi tunas, saat muncul akar, panjang akar, jumlah akar, saat muncul daun dan jumlah daun. Data yang diperoleh dianalisis menggunakan analisis deskriptif karena dari uji kenormalan data, data tidak dapat dianalisis menggunakan analisis ragam. Media yang digunakan dalam penelitian ini adalah MS (Murashige dan Skoog) dengan kombinasi perlakuan ZPT IBA dan BAP masing-masing konsentrasi $0,1,2$, 3, dan 4 ppm.

\section{HASIL DAN PEMBAHASAN}

\section{Saat Kemunculan Tunas}

Munculnya tunas merupakan indikator untuk mengetahui pertumbuhan dan perkembangan eksplan dalam budidaya secara in vitro. Pada tabel 1 menunjukkan bahwa tidak semua perlakuan dapat menumbuhkan tunas hingga periode pengamatan berakhir, hal ini disebabkan oleh beberapa hal diantaranya, media yang telah tercampur oleh senyawa kimia sebagai hasil dari aktivitas antimikroba 
Tabel 1. Rata-rata waktu muncul tunas (HST) dengan berbagai konsentrasi IBA dan BAP

\begin{tabular}{|c|c|c|c|c|c|c|c|c|c|c|c|c|c|c|c|c|}
\hline \multirow{3}{*}{$\begin{array}{l}\text { IBA } \\
(\mathrm{ppm})\end{array}$} & \multicolumn{15}{|c|}{ BAP (ppm) } & \multirow{3}{*}{ Rata-rata } \\
\hline & \multicolumn{3}{|c|}{0} & \multicolumn{3}{|c|}{1} & \multicolumn{3}{|c|}{2} & \multicolumn{3}{|c|}{3} & \multicolumn{3}{|c|}{4} & \\
\hline & 1 & 2 & 3 & 1 & 2 & 3 & 1 & 2 & 3 & 1 & 2 & 3 & 1 & 2 & 3 & \\
\hline 0 & 6 & - & - & 6 & - & - & 7 & - & - & 7 & 5 & 9 & 4 & - & - & 6,3 \\
\hline 1 & 4 & - & - & - & - & - & 4 & 4 & 9 & 7 & 5 & - & 11 & - & - & 6,3 \\
\hline 2 & 4 & - & - & 8 & - & - & 7 & - & - & 7 & - & - & 6 & - & - & 6,4 \\
\hline 3 & 4 & - & - & 5 & - & - & 4 & - & - & - & - & - & 10 & - & - & 5,8 \\
\hline 4 & 12 & - & - & 5 & 7 & - & 11 & - & - & 7 & - & - & - & - & - & 8,4 \\
\hline $\begin{array}{l}\text { Rata- } \\
\text { rata }\end{array}$ & \multicolumn{3}{|c|}{6} & \multicolumn{3}{|c|}{6,2} & \multicolumn{3}{|c|}{6,6} & \multicolumn{3}{|c|}{6,7} & \multicolumn{3}{|c|}{7,8} & \\
\hline Keter & & $\begin{array}{l}\mathrm{HS} \\
\mathrm{pp}\end{array}$ & & & $\begin{array}{l}\text { Sete } \\
\text { Per } 1 \\
\text { Mu }\end{array}$ & & & & & & & & & & & \\
\hline
\end{tabular}

yang dihasilkan oleh eksplan kunir putih. Selain itu tingginya kontaminasi juga menghambat terbentuknya tunas pada eksplan kunir putih.

Kontaminasi yang terjadi di dominasi oleh kontaminan internal yang berasal dari dalam eksplan (endofit) berupa jamur dan bakteri. Jamur-jamur endofit umumnya memproduksi metabolit sekunder dan banyak ditemukan pada berbagai jenis tumbuhan terutama pada tanaman obat (Sinaga et al. 2009). Waktu yang diperlukan eksplan untuk menumbuhkan tunas berkisar antara 4 HST hingga 11 HST. Kebanyakan tunas muncul pada 4 HST dengan perlakuan IBA 0 ppm, 1 ppm, 2 ppm dan 3 ppm. Sedangkan pada perlakuan pemberian BAP 3 ppm tunas banyak muncul pada 7 HST. Pemberian IBA dan BAP pada media terbukti dapat memacu induksi tunas pada eksplan, seperti yang dikemukakan oleh Lestari (2011) bahwa kombinasi sitokinin dan auksin dapat memacu morfogenesis pembentukan tunas.

\section{Jumlah Tunas}

Jumlah tunas mengindikasikan keberhasilan dalam multiplikasi. Semakin banyak tunas yang terbentuk makan semakin tinggi tingkat multiplikasinya. Pada tabel 2 terlihat bahwa kisaran jumlah tunas yang muncul antara 1-2 buah pada tiap eksplannya. Jumlah tunas terbanyak terdapat pada pemberian IBA 0 ppm dan BAP 3 ppm yakni 3, selain itu pada perlakuan IOB4, I1B2, I2B3 dan I4B1 juga mampu menginduksi jumlah tunas yang cukup banyak yakni dua tunas, sedang perlakuan yang lain hanya dapat menginduksi satu tunas.

Diduga pada konsentrasi BAP 3 ppm merupakan konsentrasi optimal yang berpengaruh positif terhadap peningkatan jumlah tunas. BAP merupakan ZPT dari jenis sitokinin yang memacu sitokenensis sel sehingga pemberian sitokinin dapat menginduksi pembentukan tunas yang lebih banyak. Petumbuhan jumlah tunas optimum terjadi pada konsentrasi IBA 3 ppm selanjutnya penambahan konsentrasi IBA justru menurunkan jumlah tunas. Hasil penelitian Suharijanto (2011) menunjukkan rendahnya jumlah eksplan yang menghasilkan tunas diduga disebabkan oleh adanya kandungan auksin endogen eksplan yang jumlahnya seimbang dengan sitokinin yang diberikan.

Wilkins (1989) menyatakan bahwa BAP merupakan golongan sitokinin aktif yang bila diberikan pada tunas pucuk akan mendorong proliferasi tunas yaitu keluarnya tunas lebih dari satu.

Tabel 2. Rata-rata jumlah tunas dengan kombinasi konsentrasi IBA dan BAP

\begin{tabular}{lcccccc}
\hline \multirow{2}{*}{ IBA $(\mathrm{ppm})$} & \multicolumn{7}{c}{$\mathrm{BAP}(\mathrm{ppm})$} & \multirow{2}{*}{ Rata-rata } \\
\cline { 2 - 6 } & 0 & 1 & 2 & 3 & 4 & \\
\hline 0 & 1 & 1 & 1 & 2 & 2 & 1.5 \\
1 & 1 & - & 1.3 & 1 & 1 & 1.1 \\
2 & 1 & 1 & 1 & 2 & 1 & 1.2 \\
3 & 1 & 1 & 1 & - & 1 & 1 \\
4 & 1 & 1.5 & 1 & 1 & - & 1.1 \\
\hline Rata-rata & 1 & 1.1 & 1.1 & 1.5 & 1.3 & \\
\hline
\end{tabular}

Keterangan : - : Tidak Ada Tunas 


\section{Tinggi Tunas}

Tinggi tunas merupakan salah satu indikator pertumbuhan eksplan. Semakin tinggi tunas maka perkembangan tanaman akan semakin baik.

Pada Tabel 3 menunjukkan bahwa rata-rata tinggi tunas tertinggi terdapat pada perlakuan I1B3 yaitu 4.8 $\mathrm{cm}$. Pada beberapa perlakuan lain seperti I2B3 dan I3B4 juga memiliki rata-rata tinggi tunas yang cukup besar yakni $4 \mathrm{~cm}$ dan $3 \mathrm{~cm}$, sedangkan rata-rata tinggi tunas terendah muncul pada perlakuan 14B0 yaitu $0.3 \mathrm{~cm}$.
Perlakuan yang dapat menumbuhkan tunas tertinggi ialah pemberian IBA 1 ppm dan BAP 3 ppm. Jika dikaitkan dengan saat muncul tunas, pemberian IBA dan BAP berpengaruh pada pertumbuhan tinggi tunas. Pada perlakuan I1B3 kebanyakan tunas muncul pada minggu pertama yakni hari ke lima setelah tanam. Eksplan yang berhasil menginduksi tunas di awal HST juga memiliki rata-rata tinggi tunas tertinggi.

Tabel 3. Rata-rata tinggi tanaman $(\mathrm{cm})$ pada berbagai konsentrasi IBA dan BAP

\begin{tabular}{lcccccl}
\hline \multirow{2}{*}{ IBA $(\mathrm{ppm})$} & \multicolumn{7}{c}{$\mathrm{BAP}(\mathrm{ppm})$} & \multirow{2}{*}{ Rata-rata } \\
\cline { 2 - 6 } & 0 & 1 & 2 & 3 & 4 & \\
\hline 0 & 0.3 & 0.5 & 0.4 & 3.7 & 0.5 & 1.3 \\
1 & 0.5 & - & 1 & 4.8 & 1 & 1.8 \\
2 & 0.7 & 0.5 & 2.5 & 4 & 0.5 & 1.6 \\
3 & 0.4 & 2 & 0.5 & - & 3 & 1.5 \\
4 & 0.3 & 0.9 & 0.5 & 1.3 & - & 0.8 \\
\hline Rata-rata & 0.5 & 1 & 1 & 3.5 & 1.3 & \\
\hline
\end{tabular}

Keterangan : - : Tidak Ada Tunas

\section{Saat Kemuncul Akar}

Akar berfungsi dalam penyerapan unsur hara dan air bagi tanaman. Semakin cepat eksplan memunculkan akar maka kebutuhan akan unsur hara akan cepat terpenuhi. Dari semua eksplan yang berhasil menginduksi tunas, tidak semua berhasil menginduksi akar, hanya sekitar $38 \%$ dari keseluruhan eksplan yang berhasil menginduksi tunas berhasil pula menginduksi tunas. Tabel 4 menunjukkan bahwa saat muncul akar berkisar dari 4 HST hingga 13 HST, namun kebanyakan tunas muncul pada $10 \mathrm{HST}$. Saat muncul akar tercepat terjadi pada perlakuan IBA $1 \mathrm{ppm}$ dan BAP $2 \mathrm{ppm}$ yakni 4 HST. Induksi akar pada eksplan dipengaruhi oleh adanya auksin yang ditambahkan.

Pemberian konsentrasi dari IBA dan BAP yang rendah telah mampu memperlihatkan persentase kemunculan akar lebih cepat yaitu 4 HST. Hal ini diduga karena beberapa faktor salah satunya karena sudah tersedianya zat tumbuh endogen dari eksplan bagi pertumbuhan akar sehingga tidak perlu lagi penambahan ZPT eksogen dalam konsentrasi yang tinggi, jika hal tersebut dilakukan maka akan menghambat kemunculan akar.

Garg (2012) mengatakan bahwa efisiensi dan efektifitas IBA yang digunakan terhadap induksi perakaran terdapat pada konsentrasi sedikit atau tanpa penambahan IBA, artinya auksin endogen yang terdapat pada tanaman ini sudah mampu menstimulasi akar, jadi hanya membutuhkan konsentrasi yang rendah untuk memicu tumbuhnya akar

Tabel 4. Rata-rata waktu muncul akar (HST) pada berbagai konsentrasi IBA dan BAP

\begin{tabular}{|c|c|c|c|c|c|c|c|c|c|c|c|c|c|c|c|c|}
\hline \multirow{3}{*}{$\begin{array}{l}\text { IBA } \\
\text { (ppm) }\end{array}$} & \multicolumn{15}{|c|}{ BAP (ppm) } & \multirow{3}{*}{ Rata-rata } \\
\hline & \multicolumn{3}{|c|}{0} & \multicolumn{3}{|c|}{1} & \multicolumn{3}{|c|}{2} & \multicolumn{3}{|c|}{3} & \multicolumn{3}{|c|}{4} & \\
\hline & 1 & 2 & 3 & 1 & 2 & 3 & 1 & 2 & 3 & 1 & 2 & 3 & 1 & 2 & 3 & \\
\hline $0 \mathrm{ppm}$ & - & - & - & - & - & - & - & - & - & - & 5 & 9 & - & 7 & - & 7 \\
\hline $1 \mathrm{ppm}$ & - & - & - & - & - & - & 4 & 4 & - & - & - & - & - & - & - & 4 \\
\hline 2 ppm & - & - & - & - & - & - & - & - & - & - & - & - & 13 & 8 & - & 10,5 \\
\hline 3 ppm & - & - & - & 10 & - & - & 7 & 4 & - & - & - & - & 6 & - & - & 6,75 \\
\hline 4 ppm & - & - & - & 10 & - & - & 8 & 10 & - & 9 & - & - & 10 & - & - & 9,4 \\
\hline $\begin{array}{l}\text { Rata- } \\
\text { rata }\end{array}$ & & - & & & 10 & & & 6,2 & & & 7,7 & & & 8,8 & & \\
\hline Keterar & & & & & & & & & & & & & & & & \\
\hline
\end{tabular}

Respon Kunir Putih (Kaempferia rotunda) terhadap Pemberian IBA dan BAP pada Kultur In Vitro 


\section{Jumlah Akar}

Akar yang terbentuk melalui proses kultur jaringan sering pula disebut akar tambahan yaitu akar yang tumbuh pada potongan tanaman atau pada kalus dalam kultur. Semakin banyak jumlah akar maka unsur hara yang diserap semakin banyak pula. Ratarata jumlah akar yang tumbuh pada eksplan kunir putih disajikan pada tabel 5 .

Dari tabel 5 terlihat bahwa kisaran rata-rata jumlah akar antara satu hingga empat buah. Jumlah akar terbanyak terdapat pada perlaukan I0B3 yaitu dengan rata-rata 4.5 akar. Pada perlakuan I3B4 dan 14B3 jumlah akar yang tumbuh juga cukup banyak yakni 4 buah. Induksi dan pertumbuhan akar pada kultur jaringan umunya dipengaruhi oleh adanya auksin. Penambahan IBA 0 ppm dan BAP 3 ppm akar mulai muncul rata-rata pada 7 HST dengan rata-rata jumlah akar cukup tinggi yaitu 4 buah, hal ini diduga bahwa eksplan sudah memiliki auksin endogen yang cukup untuk menginduksi akar sehingga hanya dibutuhkan sedikit penambahannya.

Penambahan sedikit auksin juga memiliki korelasi positif antara waktu kemunculan akar dan jumlah akar yang dapat dihasilkan. Hal ini sesuai dengan pernyataan Rostiana (2007), bahwa IBA mempunyai aktivitas sebagai hormon akar, sehingga aktivitas IBA dapat berpengaruh terhadap jumlah akar. Jika pemberian IBA terlalu tinggi, dapat menghambat pertumbuhan akar, hal ini juga diduga bahwa telah tersedianya auksin endogen sehingga dengan penambahan auksin eksogen dapat menghambat proses pembentukan akar.

Tabel 5. Rata-rata jumlah akar pada berbagai konsentrasi IBA dan BAP

\begin{tabular}{lcccccl}
\hline \multirow{2}{*}{ IBA $(\mathrm{ppm})$} & \multicolumn{7}{c}{$\mathrm{BAP}(\mathrm{ppm})$} & \multirow{2}{*}{ Rata-rata } \\
\cline { 2 - 6 } & 0 & 1 & 2 & 3 & 4 & \\
\hline 0 & - & - & - & 4.5 & 2 & 3.3 \\
1 & - & - & 2 & - & - & 2 \\
2 & - & - & - & - & 2.5 & 2.5 \\
3 & - & 3 & 1.5 & - & 4 & 2.8 \\
4 & - & 3 & 1.5 & 4 & 1 & 2.4 \\
\hline Rata-rata & - & 3 & 1.7 & 4.3 & 2.4 & \\
\hline
\end{tabular}

Keterangan : - : Tidak Ada Akar.

\section{Panjang Akar}

Panjang akar berhubungn dengan jangkauan dalam mendapatkan unsur hara pada tanah atau media tumbuhnya. Semakin panjang akar maka luas jangkauan penyerapannya akan lebih luas. Dari tabel 6 menunjukkan bahwa rata-rata panjang akar tertingi terdapat pada perlakuan pemberian IBA $0 \mathrm{ppm}$ dan BAP $3 \mathrm{ppm}$ yakni $5.2 \mathrm{~cm}$, sedangkan rata-rata panjang akar terendah terdapat pada pemberian perlakuan 10B4, I1B2 dan 14B4. Diantara beberapa tipe auksin yang sering digunakan, IBA adalah auksin yang paling efektif untuk memproduksi akar pada pangkal tunas.

Perlakuan yang hasilnya tinggi yaitu pada perlakuan IOB3 dan I3B4. Jumlah dan panjangnya akar yang dihasilkan akan menguntungkan dari tanaman itu sendiri karena akan lebih mempermudah dalam hal penyerapan nutrisi serta jangkauan yang lebih luas. Hasil rata-rata data yang ada menunjukkan bahwa pada pemberian BAP 3 ppm dengan berbagai konsentrasi dari IBA mulai dari terkecil hingga konsentrasi besar akan menghasilkan rata-rata panjang akar $3 \mathrm{~cm}$.

Tabel 6. Rata-rata panjang akar pada berbagai konsentrasi IBA dan BAP

\begin{tabular}{lcccccc}
\hline \multirow{2}{*}{ IBA $(\mathrm{ppm})$} & \multicolumn{7}{c}{$\mathrm{BAP}(\mathrm{ppm})$} & \multirow{2}{*}{ Rata-rata } \\
\cline { 2 - 6 } & 0 & 1 & 2 & 3 & 4 & \\
\hline 0 & - & - & - & 5.2 & 0.4 & 2.8 \\
1 & - & - & 0.4 & - & - & 0.4 \\
2 & - & - & - & - & 0.7 & 0.7 \\
3 & - & 0.5 & 0.7 & - & 4.5 & 1.9 \\
4 & - & 0.9 & 0.6 & 0.8 & 0.4 & 0.7 \\
\hline Rata-rata & - & 0.7 & 0.6 & 3 & 1.5 & \\
\hline
\end{tabular}

Keterangan : - : Tidak ada akar

\section{Saat Kemunculan Daun}

Daun merupakan bagian dari tumbuhtumbuhan yang mempunyai fungsi dan peran penting untuk kelangsungan hidup tumbuh-tumbuhan itu sendiri.

Dari tabel 7 terlihat bahwa hanya sekitar $8 \%$ ekplan yang berhasil menumbuhkan daun. Daun mulai tumbuh berkisar antara $21 \mathrm{HST}$ hingga $36 \mathrm{HST}$.
Nilai median terendah terdapat pada perlakuan pemberian BAP $3 \mathrm{ppm}$, yaitu $24.5 \mathrm{HST}$, itu berarti pada pemberian BAP dengan konsentrasi tinggi mampu menumbuhkan daun lebih cepat dari perlakuan yang lain dan pada konsentrasi ini merupakan konsentrasi yang optimum karena pada BAP 4 ppm nilai mediannya 27 HST. Median tertinggi 
terdapat pada pemberian BAP 2 ppm dengan berbagai konsentrasi pemberian IBA, yakni 28 HST.

Penggunaan zat pengatur tumbuh dengan konsentrasi yang tepat akan menaikkan hasil, sedangkan pada konsentrasi yang tinggi dapat menghambat pertumbuhan, meracuni bahkan mematikan tanaman. Keberhasilan aplikasi zat pengatur tumbuh ditentukan oleh beberapa faktor, diantaranya adalah konsentrasi yang digunakan harus tepat, metode pemberian pada tanaman, waktu pemberian yang tepat, dan kombinasi ZPT yang digunakan.

Tabel 7. Rata-rata waktu muncul daun (HST) pada berbagai konsentrasi IBA dan BAP

\begin{tabular}{|c|c|c|c|c|c|c|c|c|c|c|c|c|c|c|c|c|}
\hline \multirow{3}{*}{$\begin{array}{l}\text { IBA } \\
\text { (ppm) }\end{array}$} & \multicolumn{15}{|c|}{ BAP (ppm) } & \multirow{3}{*}{-Rata-rata } \\
\hline & \multicolumn{3}{|c|}{0} & \multicolumn{3}{|c|}{1} & \multicolumn{3}{|c|}{2} & \multicolumn{3}{|c|}{3} & \multicolumn{3}{|c|}{4} & \\
\hline & 1 & 2 & 3 & 1 & 2 & 3 & 1 & 2 & 3 & 1 & 2 & 3 & 1 & 2 & 3 & \\
\hline 0 & - & - & - & - & - & - & - & - & - & 21 & - & 36 & - & - & - & 28,5 \\
\hline 1 & - & - & - & - & - & - & - & - & - & 24 & - & - & - & - & - & 24 \\
\hline 2 & - & - & - & - & - & - & 28 & - & - & 25 & - & - & - & - & - & 26.5 \\
\hline 3 & - & - & - & - & - & - & - & - & - & - & - & - & 27 & - & - & 27 \\
\hline 4 & - & - & - & - & - & - & - & - & - & - & - & - & - & - & - & - \\
\hline Rata-rata & & - & & & - & & & 28 & & & 26,5 & & & 27 & & \\
\hline
\end{tabular}

\begin{tabular}{ccl}
\hline Keterangan : & HST & : Hari Setelah Tanam \\
ppm & : Part Per Million \\
- & : Tidak Muncul Daun.
\end{tabular}

\section{Jumlah Daun}

Jumlah daun berkaitan dengan proses fotosintesis tanaman karena daun mengandung klorofil sebagai tempat berlangsungnya proses fotosintesis. Semakin banyak daun yang dimiliki maka hasil fotosintesis juga semakin banyak.

Pada tabel 8. telihat bahwa hanya $8 \%$ dari seluruh sampel yang dapat menumbuhkan daun. Daun yang tumbuh berkisar antara satu hingga dua helai per tanamannya. Jumlah daun tertinggi terdapat perlakuan pemberian IOB3,

I1B3 dan I2B3 ppm, yaitu 2 helai daun. Sedangkan jumlah daun terendah terdapat pada perlakuan I2B2 dan I3B4 yaitu satu helai daun.
Pertumbuhan daun pada kultur jaringan di pengaruhi oleh sitokinin yang salah satu fungsi utamanya adalah untuk memicu organogenesis pada eksplan. Pada penelitian ini daun banyak tumbuh pada pemberian BAP 3 ppm pada berbagai konsentrasi IBA. Dapat diduga pemberian BAP 3 ppm merupakan konsentrasi dari sitokinin yang optimal jika diberikan pada kultur kunir putih, mengingat pemberian dosis yang lebih rendah atau lebih tinggi justru tidak memunculkan daun atau hanya muncul satu helai daun, seperti pada hasil rata-rata pemberian konsentrasi BAP 2 ppm dan 4 ppm.

Tabel 8. Rata-rata jumlah daun pada berbagai konsentrasi IBA dan BAP

\begin{tabular}{lllllll}
\hline \multirow{2}{*}{ IBA $(\mathrm{ppm})$} & \multicolumn{7}{c}{ BAP $(\mathrm{ppm})$} & \multicolumn{2}{c}{ Rata-rata } \\
\cline { 2 - 6 } & 0 & 1 & 2 & 3 & 4 & 2 \\
\hline 0 & - & - & - & 2 & - & 2 \\
1 & - & - & - & 2 & - & 1.5 \\
2 & - & - & 1 & 2 & 1 & 1 \\
3 & - & - & - & - & - & - \\
4 & - & - & - & - & 1 & \\
\hline Rata-rata & - & - & 1 & 2 & 1 \\
\hline
\end{tabular}

Keterangan : - : Tidak Ada Daun.

\section{KESIMPULAN DAN SARAN}

Perlakuan IBA pada beberapa konsentrasi mampu memunculkan tunas, namun tidak mampu memunculkan akar dan daun. Perlakuan BAP pada konsentrasi 3 ppm mampu memunculkan tunas paling banyak yaitu 2 buah, memiliki akar paling panjang yaitu $5,2 \mathrm{~cm}$ dan memunculkan daun paling cepat yaitu 21 HST. Perlakuan IBA 2 ppm + BAP 3 ppm menghasilkan tunas paling banyak yaitu 2 buah, memiliki akar paling panjang yaitu $4,5 \mathrm{~cm}$ pada perlakuan IBA 3 ppm + BAP 4 ppm, dan memunculkan daun paling cepat yaitu $24 \mathrm{HST}$ pada perlakuan IBA $1 \mathrm{ppm}+$ BAP $3 \mathrm{ppm}$. Berdasarkan penelitian ini, perlu dilakukan penelitian lebih lanjut mengenai konsentrasi IBA dan BAP yang optimal untuk perbanyakan kunir putih secara kultur jaringan, serta dengan metode sterilisasi yang berbeda agar hasil yang didapatkan lebih baik lagi. 


\section{DAFTAR PUSTAKA}

Arniputri RB, Praswanto Purnomo D. 2003. Pengaruh Konsentrasi IAA dan BAP terhadap Pertumbuhan dan Perkembangan Tanaman Kunir Putih. J Agrosains 5(2): 48-51.

Atun S, Arianingrum R. 2015. Anticancer activity of bioactive compounds from Kaempferia rotunda rhizome against human breast cancer. International J Phar Phytochem Res 7(2): 262-269.

Garg P. 2012. Multiple shoot an efficient root induction in Cisssus quadrangularis. International J. Phar Clinic Res 4(1) : 4-10.

Hendaryono, Daisy P S, Ari Wijayani. 1994. Teknik kultur jaringan. Yogyakarta (ID): Kanisius.

Lestari EG 2011. Peranan zat pengatur tumbuh dalam perbanyakan tanaman melalui kultur jaringan. J. Agro Biogen 7(1):63-68.
Nisak K, Nurhidayati T, Purwani KI 2012. Pengaruh kombinasi konsentrasi ZPT NAA dan BAP pada kultur jaringan tembakau Nicotiana tabacum var. Prancak 95. J Sains Seni Pomits 1(1): 1-6.

Rostiana, O, Seswita D. 2007. Pengaruh indole-3butyric acid dan naphtaleine acetic acid terhadap induksi perakaran tunas piretrum (Chrysanthemum cinerariifolium (trevir.)vis.) klon prau 6 secara in vitro. Bul. Litro 18(1): 39-48.

Sinaga E, Noverita dan Fitria D 2009. Daya antibakteri jamur endofit yang diisolasi dari daun dan rimpang lengkuas (Alpinia galangal Sw.). J Farm Indo 4(4): 161-70.

Suharijanto. 2011. Induksi tunas jeruk pamelo (Citrus maxima Merr) kultivar Bageng secara In vitro dengan pemberian jenis dan konsentrasi sitokinin. Tesis. Universitas Sebelas Maret.

Wilkins MB. 1989. Fisiologi tumbuhan. Cetakan Kedua. Jakarta (ID): Bina Aksara. 